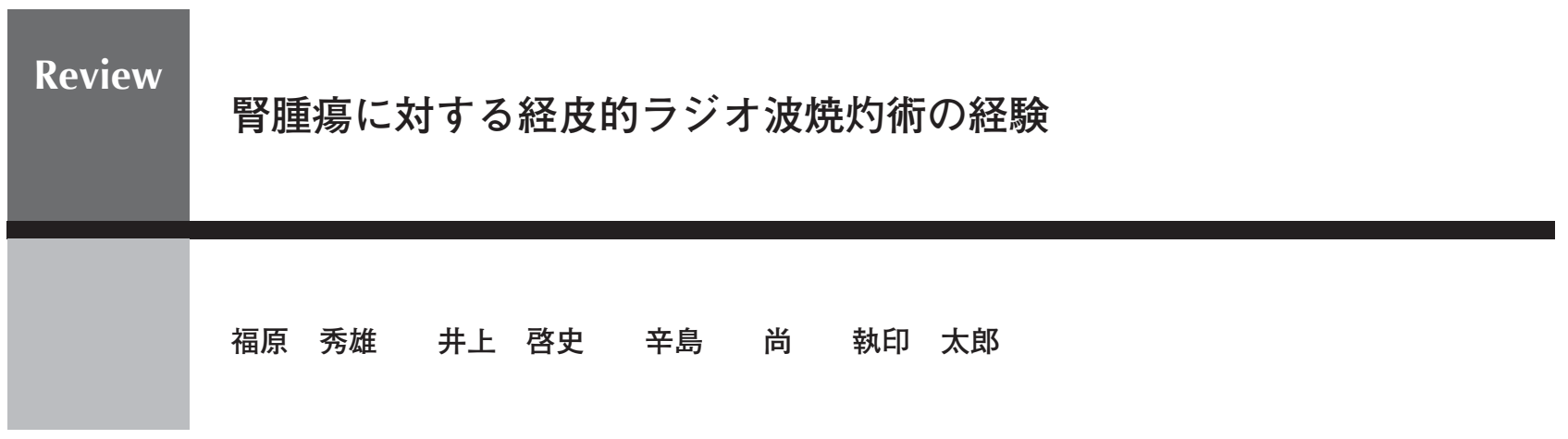

\title{
Clinical experience of percutaneous radiofrequency ablation of renal cell carcinoma
}

Hideo Fukuhara, Keiji Inoue, Takashi Karashima and Taro Shuin

\begin{abstract}
Purpose: Percutaneous radiofrequency ablation for renal tumor could be a useful modality as minimally invasive and palliative therapy. In this study we evaluated their feasibility and safety.

Methods: Between 2004 and 2011, real-time CT guided radiofrequency ablation was perfomed to ablate a total of 16 tumors in 13 patients. We recorded whether tumors were successfully ablated, major complications and changes of creatinine clearance before and after RFA.

Results: Overall 11 of $13(84.6 \%)$ were successfully ablated with radiofrequency ablation but 2 had local recurrent tumors. There was no significant change in creatinine clearance between before and after RFA. Two minor complications as pararenal hemorrhage were observed.

Conclusion: Percutaneous radiofrequency is a feasible and safe modality as a minimally invasive therapy.
\end{abstract}

Key words: renal cell carcinoma, radiofrequency ablation, creatinine clearance

Accepted on Oct. 18, 2011

\section{高知大学医学部腫瘍病態学腎泌尿器制御学教室}

Department of Urology, Kochi Medical School

Address: Okouchoukohasu, Nankokushi-city, Kochi, 783-8505, Japan

Tel: +81-88-880-2402 Fax: +81-88-880-2404 e-mail: jm-fukuhara@kochi-u.ac.jp 


\section{諸 言}

近年，画像診断技術の発達と検診の普及により無症候 性の腎腫瘍が診断される機会が増加した。こういった腎 腫瘍に対しては，なるべく低侵襲性で腎機能を温存した 治療法が望まれる。消化器領域においては, 経皮的ラジ オ波焼灼術（radio-frequency ablation：RFA）は肝腫瘍 に対する低侵襲な治療法として有効性が確立されてい

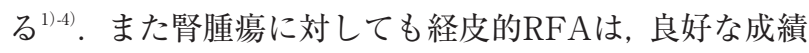
が報告されている ${ }^{5)-11}$. さらに，腎腫瘍に対する経皮的 RFAは, 治療による腎機能低下を最小限に抑えることが できる，今回我々は，腎腫瘍 13 症例に対して経皮的RFA を施行し, その有効性および治療前後の腎機能を測定す ることにより安全性を検討した。

\section{I. 対象と方法}

\section{1. 対象 (Table 1)}

2003年 6 月 30 日に本学倫理委員会の承認を得た後, 2004年〜2011年の 8 年間に当科で13症例に対して経皮的 RFAを施行した. 全13症例, 平均年齢 64.6 (38〜 82) 歳, 男性11例, 女性 2 例, 全16腫瘍に対して経皮的RFAを施 行した. そのうち, Von Hippel-Lindau病に伴う遺伝性多 発腎癌 3 例, 両側性腎腫瘍 7 例, 単腎症例 5 症例であっ た。また, RFA施行 5 日から 7 日前に, iodized oil (リ ピオドールウルトラフルイド ${ }^{\circledR}+99.5 \%$ エタノール混合 液による選択的腫瘍動脈塞栓術（TAE）を 3 症例に施行 した。

\section{2. ラジオ波凝固装置}

凝固装置はRadionic社製Cool-tip RF system（内部冷 却式直針電極）を使用した。 $480 \mathrm{KHz}$ の高周波により発 生するジュール熱により治療を行った，穿刺針はシング ルプローブ $17 \mathrm{G}$, 凝固範囲は $2 \sim 3 \mathrm{~cm}$ ののを用いた.

\section{3. 凝固方法}

ラジオ波凝固装置を用いて, 局所麻醉下にreal-time CTガイド下に経皮的RFAを施行した。 通常は $40 \mathrm{~W} り$ 通電凝固を開始し，その間にインピーダンスの急上昇に

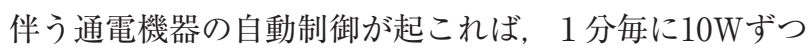
出力を上げた。初期インピーダンスより $20 \Omega$ 上昇した時 点をend-pointに設定し, 通電停止後は腫瘍内の標的温度

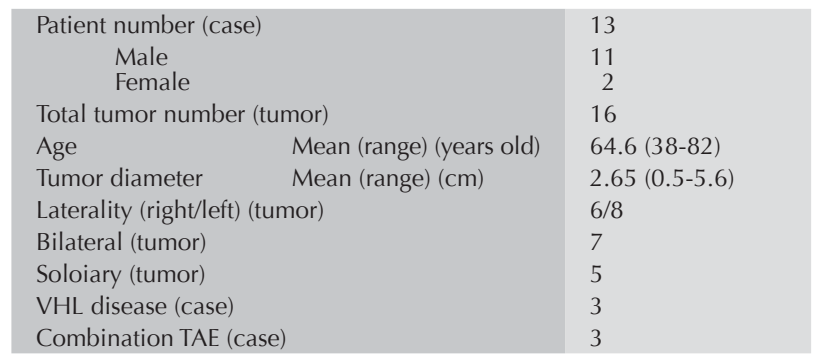

Table 1 Patients' characteristics

We performed percutaneous radiofrequency ablation for 13 RCC patients.

は $60^{\circ} \mathrm{C}$ 以上に到達していれば凝固終了とした.

\section{4. 腎機能評価}

治療前と治療 1 週間後に血清クレアチニン $(\mathrm{Cr})$ を測 定し，その血清Cr值よりクレアチニン・クリアランス （Ccr）を算出した.

Ccr值はCockroft-Gaultの換算式 $[(140-$ 年齢 $) \times($ 体重 $\mathrm{kg}) / 72 \times$ 血清 $\mathrm{Cr}$ 值 $(\mathrm{mg} / \mathrm{dL})]$ を用いて算出した.さら に, 治療前後でのCcr值を比較しPaired- $t$ testにて検討し た. 統計学的に $\mathrm{p}<0.05$ 有意水準と判定した. 透析患者 は除外した。

\section{5. 治療評価}

治療 3 力月後に造影CTにて画像評価を行い, 腫瘍书 よび造影効果の有無を確認し, 局所制御としての効果判 定を行い, 無再発率を算出した。

\section{II. 結果}

経皮的RFAを施行した全13症例・16腫瘍において, 評 価可能であった. 観察期間中央值は25.9力月で, 16 腫瘍 のうち 14 腫瘍 $(87.5 \%)$ で造影効果は消失, 腫瘍は縮小 し治療効果を認め, 2 腫瘍 (12.5\%) において局所再発 を認めた. 局所再発を認めた 2 腫瘍はいずれも $5 \mathrm{~cm}$ 以 上の大きな腫瘍であった（Fig. 1).

血清Cr值より算出したCcr值は，治療前は72.4 \pm 38.9 (25.5 151.9) $\mathrm{mL} / \mathrm{min}$ で, 治療後Ccr值は66.1 438.1 （24.3〜 151.9） $\mathrm{mL} / \mathrm{min}$ であった. 治療前のCcr值と治療 後のCcr值との間には有意差は見られず (paired- $t$ test, $\mathrm{p}=$ 0.69), 治療によるCcr值への影響は認められなかった (Fig. 2).このように経皮的RFA前後で腎機能の有意な 


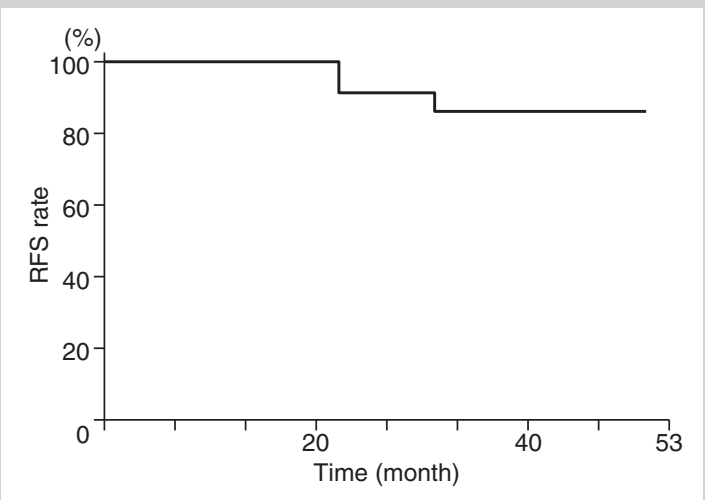

Figure 1 Recurrent-free survival

Kaplan-Meier recurrent-free survival analysis in 13 patients.

変動は認められなかった．また，透析導入となった症例 は認められなかった。

そして今回の検討においては，尿瘦などの重篤な合併 症は認められず, 2 症例において腎周囲血腫を認めたが, いずれの症例も保存的治療により軽快した。

\section{III. 考察}

1950年にVermootenによる腎部分切除術の最初の報 告以来, 腎部分切除術は腎機能低下例や単腎など根治術 不能例を中心に施行されてきた ${ }^{122}$.

現在は，対側腎が健常である症例においても患側腎温 存性が試みられ根治的腎摘除術と同等の成績が報告され ている ${ }^{13-15)}$. また最近では腹腔鏡下腎部分切除術も試み られているが, 正確な運針や結紮など高い技術レベルが 要求され, さらに腫瘍のサイズ・部位でその適応は制限 される。

1997年にZlottaらが腎癌に対するRFAの最初の治療経 験を報告5) して以来, いくつかの治療経験が報告されて いる(6)-11). そのRFAによる局所制御率は86.5〜100\%と報 告され，良好な成績が得られている。しかし，長期間に おける成績や, 多数症例での大規模な臨床試験は未だ実 施されておらず，今後はこれらの検証が待たれる.

RFAはラジオ波により発生するジュール熱と誘導熱 により組織を凝固壊死させる治療法である，腫瘍細胞の 熱変性は $46^{\circ} \mathrm{C}$ よ始まり, $50 \sim 52^{\circ} \mathrm{C} ・$ 約 5 分間で細胞死

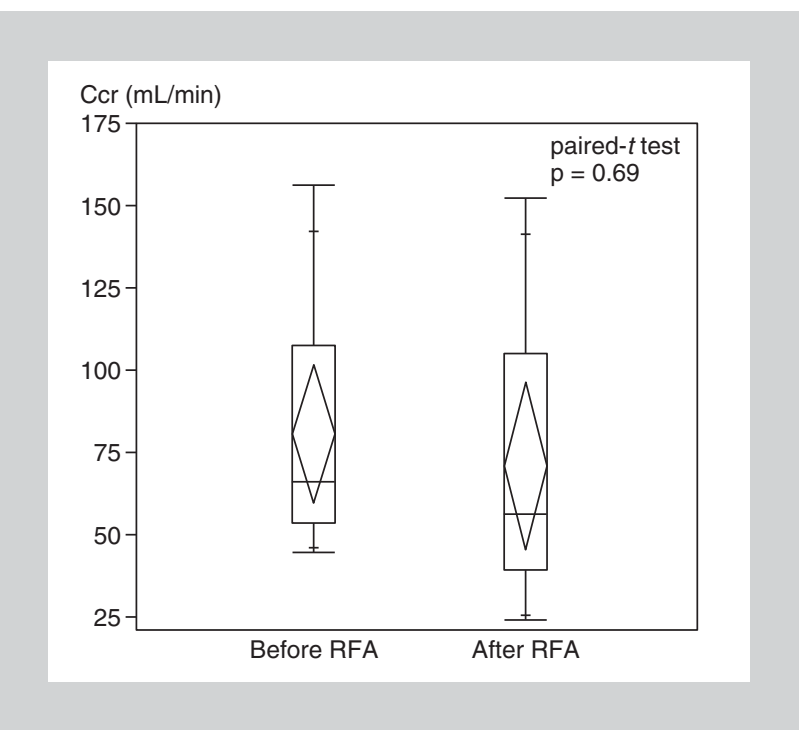

Figure 2 The change of creatinine clearance before and after RFA

There was no significant change between before and after RFA.

が誘導される. $60^{\circ} \mathrm{C}$ 以上に達すると瞬間的に細胞死に至 る. $105^{\circ} \mathrm{C}$ 以上で腫瘍細胞は沸騰し炭化を来たす. 腫瘍内 の標的温度が50 $100^{\circ} \mathrm{C}$ に到達できれば有効な治療効果 が期待できる ${ }^{1617)}$.

また消化器癌領域では, 特に肝臓の肝細胞癌に対して 低侵襲性治療として経皮的RFAが盛んに行われ, その有 効性が確立している. 経皮的RFAによる局所制御率は 85〜90\%以上であり, 局所再発率は10～20\%に認められ， 肝機能に影響を与えることなく良好な治療効果を得るこ とができる ${ }^{1-4)}$.

一般的に腎腫瘍に対する経皮的RFAの治療成績は, 無 再発率80 90\%との報告があり ${ }^{5)-11)}$, 今回の検討におけ る無再発率は $87.5 \%$ であり, これまでの報告と今回の成 績はほぼ同等であった，今回の検討において再発を来し た 2 症例は, いずれの症例においても腫瘍サイズは 5 cm以上であり, $3 \mathrm{~cm}$ 超える大きな腫瘍であった．この ように, $3 \mathrm{~cm}$ 超える大きな腫瘍は経皮的RFA単独治 療では治療効果は不十分であり, その他の併用治療が必 要であると考えられる. そこで $3 \mathrm{~cm}$ 以上の腎腫瘍は経 皮的RFA単独治療では腫瘍制御が難しく, TAE併用に ついては未だ有効性が確立されていないが, TAE併用 経皮的RFA治療で解決できる可能性がある. しかし今回 の検討で, 1 症例はTAEを併用し経皮的RFAを行った 
が再発を来しており，そのような症例には，インター フェロンやIL-2などのサイトカイン療法やtyrosine kinase inhibitorのような分子標的治療などの追加治療が 必要であると考えられる.

肝臓癌においても $3 \mathrm{~cm}$ 以上の大型hepatocellular carcinomaは，TAE併用経皮的RFAにて肝切除と同等の 成績であるとの報告もあり，腎腫瘍に対する TAE併用 経皮的RFAは今後さらなる検討が期待される ${ }^{18)-22)}$.

腎機能については, 経皮的RFA前のCcr值と経皮的 RFA後のCcr值の間に有意な変化は認められず，治療に よる影響で腎機能の悪化は最小限のものに抑えられてい たと考えられる.これは，経皮的RFAによる焼灼の影響 を受ける正常腎実質の範囲がわずかなものであり，腎機 能が温存されているものと思われる.このような今回の 結果は, 経皮的RFAが腎機能に対しては非常に低侵襲で あり，単腎症例であっても良好なQOLを提供してくれる ことを示している. 経皮的RFAの腎機能に対する長期的 な影響については不明であり, さらなる検討が必要であ る.

経皮的RFAの合併症は 7 〜 $2.4 \%$ に発生するとの報告
があるが，多くのものは軽微なものであり保存的加療で 対応可能である. 重大な合併症としては尿管動脈瘦, 尿 管穿孔，尿管狭窄などがあり，これらの合併症に対して は塞栓術, 尿管ステント留置といった処置が必要となる. 軽微な合併症としては腎周囲血腫, 血尿, 高血圧, 区域 性腎梗塞などがあり，これらの合併症は保存的加療で対 応可能である。また稀なものとしては気胸, 皮膚転移な どがある，特に単腎で経皮的RFAを行う場合は，血尿に よって尿管閉塞を来し，急性腎不全に至る場合があるの で注意が必要となる。

今回の検討においては 2 症例 $(15.4 \%)$ に腎周囲血腫 を認めたが, いずれも経過観察による保存的治療にて軽 快した. その他, 重篤な合併症は認められず, 安全に施 行できた。

このように有転移症例における局所制御率や治療によ る予後改善効果については未だ検討はされておらず，今 後の検討が必要であるが, 腎腫瘍に対する経皮的RFAは 低侵襲性かつ腎機能温存性を考慮すれば，高齢者，合併 症にて根治術不能例, 単腎症例, 多発症例においても十 分有効な治療法であると思われる.

\section{References}

1) Li SM, Lin CJ, Lin CC, Hsu CW, Chen YC : Randomized controlled trial comparing percutaneous radiofrequency thermal ablation, percutaneous ethanol injection, and percutaneous acetic acid injection to treat hepatocellular carcinoma of 3cm or less. Gut 54: 1151-1156, 2005

2) Shiina S, Teratani T, Obi S, Sato S, Tateishi R, Fujishima T, Ishikawa T, Koike Y, Yoshida H, Kawabe T, Omatta M : A randomized controlled trial of radiofrequency ablation with ethanol injection for small hepatocellular carcinoma. Gastroenterology 129: 122-130, 2005

3) Orlando A, Learndro G, Olivo M, Andriulli A, Cottone A : Radiofrequency thermal ablation vs. percutaneous ethanol injection for small hepatocellular carcinoma in cirrhosis: meta-analysis of randomized controlled trials. Am J Gastroenterol 104: 514-524, 2009

4) Brunello F, Veltri A, Carucci P, Pagano E, Ciccone G, Moretto P, Sacchetto P, Gandini G, Rizzetto M : Radiofrequency ablation versus ethanol injection for early hepatocellular carcinoma: A randomized controlled trial. Scand J Gastroenterol 43: 727-735, 2008

5) Zlotta AR, Wildschutz T, Raviv G, Peny MO, van Gansbeke D, Noel JC, Schulman CC : Radiofrequency interstitial tumor ablation (RITA) is a possible new modality for treatment of renal cancer : ex vivo and in vivo experience. J Endourol $11: 251-258,1997$

6) Varkarakis IM, Allaf ME, Inagaki T, Bhayani SB, Chan DY, Su LM : Percutaneous radiofrequency ablation of renal masses : result at 2-year mean followup. J Urol 174: 456-460, 2004

7) Lewin JS, Nour SG, Connell CF, Sulman A, Duerk JL, Resnick MI, Haaga JR : Phase II clinical trial of interactive MR imaging-guided interstitial radiofrequency thermal ablation of primary kidney tumors: initial experience. Radiology 232: 835-845, 2004

8) Arzola J, Baughaman SM, Hernandez J, Bishoff JT : Computed-tomography guided, resistance-based, percutaneous radiofrequency ablation of renal malignancies under conscious sedation at two years of follow-up. Urology 68: 983-987, 2006

9) Park S, Anderson JK, Matsumoto ED, Lotan Y, Josephs S, Cadeddu JA : Radiofrequency ablation of renal tumors : intermediate-term results. J Endourol 20: 569573,2006

10) McDougal WS, Gervia DA, McGovern FJ, Mueller PR : Long-term follow up of patients with renal cell carcinoma treated with radio frequency ablation with curative intent. J Urol 174: 61-63, 2005

11) Levinson AW, Su LM, Agarwal D, Sroka M, Jarrett TW, Kavoussi LR, Solomon SB : Long-term oncological and overall outcomes of percutaneous radio frequency ablation in high risk surgical patients with a solitary small renal mass. J Urol 180: 499-504, 2008

12) Vermooten V : Indication for conservative surgery in certain renal tumors: a study based on the growth pattern of the clear cell carcinoma. J Urol $64: 200-208$, 1950

13) Steinbach F, Stockle M, Muller SC, Thuroff JW, Melchior SW, Stein R, Hohenfellner R : Conservative surgery of renal cell tumors in 140 patients: 21 years of experience. J Urol 148: 24-30, 1992

14) Licht MR, Novick AC, Goormastic M: Nephron sparing surgery in incidental versus suspected renal cell carcinoma. J Urol 152: 39-42, 1994 
15) Hirao Y, Fujimoto K, Yoshii M, Tanaka N, Hayashi Y, Momose H, Samma S, Okajima E, Uemura H, Yoshida K, Ozono S : Non-ischemic nephron-sparing surgery for small renal cell carcinoma: complete tumor enucleation using a microwave tissue coagulat. Jpn J Clin Oncol 32: 95-102, 2002

16) Keiji I, Takashi K, Tatsuo I, Shingo A, Masayuki K, Taro S, Parijatha R, Atsushi K, Mutsuo F, Akimitsu H : Pathobiological influence of a radiofrequency ablation system. Pathobiology 77: 64-77, 2010

17) Inoue K, Yamasaki I, Fukata S, Iiyama T, Karashima T, Shuin T, Kurabayashi A, Ohtsuki Y, Hatta A : Evaluation of the effects of microwave tissue coagulation, radiofrequency ablation or ultrasonically-activated scalpel on renal tissue as a minimally invasive therapy. Nihon Hinyoukika Gakkai Zasshi 98: 808-818, 2007

18) Bruix J, Sherman M; Practice Guidelines Committee, American Association for the Study of Liver Diseases : Management of hepatocellular carcinoma. Hepatology 42: 1208-1236, 2005

19) Kirikoshi H, Saito S, Yoneda M, Fujita K, Mawatari H, Uchiyama T, Higurashi T, Goto A, Takahashi H, Abe Y, Inamori M, Kobayashi N, Kubota K, Sakaguchi T, Ueno N, Nakajima A : Outcome of transarterial chemoembolization monotherapy, and in combination with percutaneous ethanol injection, or radiofrequency ablation therapy for hepatocellular carcinoma. Hepatol Res 39: 553-562, 2009

20) Peng ZW, Chen MS, Liang HH, Gao HJ, Zhang YJ, Li QJ, Zahng YQ, Lau YW : A case-control study comparing percutaneous radiofrequency ablation alone or combined with transcatheter arterial chemoembolization for hepatocellular carcinoma. Eur J Surg Oncol 36: 257-263, 2010

21) Yamakado K, Nakatsuka A, Takaki H, Yokoi H, Usui M, Sakurai H, Isaji S, Shiraki K, Fuke H, Uemoto S, Takeda K : Early-stage hepatocellular carcinoma: radiofrequency ablation combined with chemoembolization versus hepatectomy. Radiology 247: 260-266, 2008

22) Kudo M : Local ablation therapy for hepatocellular carcinoma: current status and future perspective. J Gastroenterol 39: 205-214, 2004 